\title{
Tamagotchi Augmented Reality yang Dilengkapi dengan Mini Games
}

\author{
Hendrawan Armanto, Informatika Institut Sains dan Teknologi Terpadu Surabaya, \\ Edwin Sidharta, Informatika Institut Sains dan Teknologi Terpadu Surabaya
}

\begin{abstract}
Abstrak - Pada saat ini, teknologi mobile telah berkembang dengan pesat. Dalam kesehariannya, manusia tidak dapat lepas dari handphone. Hal ini menyebabkan munculnya berbagai aplikasi dan game yang bertujuan tentu saja untuk membantu ataupun memberikan kesenangan kepada penggunanya. Saat ini perkembangan game, juga sangat pesat dan telah mencapai titik dimana berbagai jenis game dikembangkan. Tidak hanya berhenti pada perkembangan jenis game, bahkan cara bermain dari game itu sendiri juga ikut berkembang. Yang dulunya permainan mobile dilakukan secara virtual, saat ini permainan sudah menyentuh area Augmented Reality (AR) dimana pemain dapat melihat bendabenda tidak nyata (buatan) dalam dunia nyata (dunia manusia). Walaupun permainan AR semakin berkembang, tetapi masih sedikit permainan AR bergenre Virtual Pet. Penelitian ini bertujuan untuk mengembangkan Permainan Virtual Pet dan mengukur tingkat kesenangan dalam memainkan permainan ini. Permainan dikembangkan dengan menggunakan Unity Game Engine dengan bantuan package AR Foundation dan penyimpanan data pada Firebase. Ujicoba akan dilakukan kepada 40 orang (pria dan wanita) pemain game yang pernah bermain virtual pet sebelumnya. Hasil akhir ujicoba menunjukan bahwa dalam segi teknis permainan berjalan dengan baik dan disukai oleh pemain akan tetapi ada sebagian pemain yang tingkat kesenangannya rendah cenderung menengah hal ini dikarenakan gambar monster yang digunakan kurang menarik dan kurangnya fitur terkait monster itu sendiri.
\end{abstract}

Kata Kunci- Game, Markerless Augmented Reality, Marker Based Augmented Reality, Virtual Pet.

\section{Pendahuluan}

$P$ erkembangan game saat ini telah sampai pada titik kemajuan yang pesat. Berbagai jenis permainan telah diciptakan. Salah satu teknologi yang digunakan untuk bermain game dan sedang berkembang pesat saat ini adalah mobile phone atau handphone. Game juga memiliki berbagai macam genre, salah satu genre dari game adalah virtual pet. Virtual pet merupakan salah satu genre game yang populer sekitar tahun 1995. Virtual pet merupakan genre game yang mengutamakan interaksi antara pemain dan peliharaan virtualnya.

Hendrawan Armanto, Departemen Informatika, Institut Sains dan Teknologi Terapan Surabaya, Surabaya, Jawa Timur, Indonesia (e-mail: hendrawan@stts.edu)

Edwin Sidharta, Departemen Informatika, Institut Sains dan Teknologi Terapan Surabaya, Surabaya, Jawa Timur, Indonesia (e-mail: edwin3@mhs.stts.edu)
Pada umumnya dalam game virtual pet juga terdapat berbagai macam mini-game, dimana setiap mini-game memiliki cara bermainnya masing-masing. Tidak seperti genre game yang lain, virtual pet pada umumnya cenderung memiliki fokus pada interaksi antar pengguna dan peliharaan virtualnya. Game yang akan dibuat akan menggunakan game engine unity dan bergenre virtual pet dengan target platform Android, Pengembangan game ini dilakukan untuk menarik minat pemain yang belum pernah mempunyai peliharaan atau yang ingin mencoba memiliki peliharaan virtual. Tujuan dari penelitian ini adalah untuk mengembangkan game berjenis virtual pet yang mengguna teknologi Augmented Reality pada platform Android dan mengukur tingkat kesenangan dari pemain game ini. Game ini akan memiliki genre virutal yang membuat pemainnya merasakan pengalaman memiliki peliharaan yang dapat berinteraksi di dunia nyata.

\section{TINJAUAN PUSTAKA}

Pada penelitian ini, digunakan beberapa komponen yang menunjang dalam pengembangan game virtual pet. Komponen yang digunakan untuk pembuatan aplikasi adalah: Unity Game Engine, Firebase, AR Foundation, Image Tracking, dan Plane Detection.

\section{A. Unity Game Engine [1]}

Unity (biasa yang kita kenal sebagai Unity3D) merupakan game engine dan IDE atau Integrated Development Environment untuk membuat media yang interaktif yang biasanya khusus untuk game. Game engine ini juga dapat mengolah gambar, grafik, suara, input, dan lain-lain.

Unity juga merupakan game engine yang bermultiplatform. Unity mampu di publish menjadi Standalone (Aplikasi berbasis dekstop), berbasis web, Android, IoS Iphone, XBOX, dan PS3. Walau bisa dipublikasi ke berbagai platform, Unity perlu lisensi untuk dapat dipublikasikan ke platform tertentu. Tetapi Unity menyediakan untuk free user dan bisa di publish dalam bentuk Standalone (.exe) dan web. Untuk saat ini Unity sedang di kembangkan berbasis AR (Augment Reality).

\section{B. Firebase Realtime Database [2]}

Firebase Realtime Database adalah database yang di-host di cloud. Data disimpan sebagai JSON (JavaScript Object Notation) dan disinkronkan secara realtime ke setiap klien yang terhubung. Ketika Anda membuat aplikasi lintasplatform dengan SDK Android, iOS, dan JavaScript, 
semua klien akan menerima update data terbaru secara otomatis.

\section{AR Foundation [3]}

AR Foundation adalah sebuah package yang ada di Unity3D untuk memudahkan developer dalam membangun sebuah aplikasi augmented reality. AR Foundation membutuhkan Plugin ARCore XR dan merupakan SDK yang digunakan dalam pembuatan game ini. Sedangkan ARCore Extensions adalah package yang menyediakan fungsionalitas ARCore tambahan yang dapat digunakan dengan AR.

\section{Image Tracking}

Image tracking merupakan salah satu fitur yang terdapat pada AR Foundation yang berfungsi agar setiap gambar berisi marker yang dideteksi oleh kamera dapat dibuatkan GameObjects, sebelum dapat mendeteksi gambar yang berisi marker tersebut diperlukan suatu ImageLibrary yang digunakan untuk menyimpan semua gambar yang dapat dideteksi oleh fitur ini.

\section{E. Plane Detection}

Plane detection merupakan salah satu fitur yang terdapat pada AR Foundation yang berfungsi agar setiap plane yang terdeteksi dibuat dalam bentuk GameObjects. Terdapat tiga mode deteksi dalam plane detection yaitu horizontal, vertikal, atau keduanya.

\section{F. Penelitian Terdahulu}

Sebelum melakukan penelitian ini, kami mempelajari terlebih dahulu beberapa penelitian yang telah ada baik terkait augmented reality ataupun penelitian terkait virtual pet tersendiri. Penelitian terakit augmented reality penting kami pelajari untuk mengetahui seberapa jauh perkembangan augmented reality saat ini sehingga teknologi augmented reality yang kami gunakan tidak tertinggal. Berikut adalah beberapa penelitian terkait augmeted reality yang kami pelajari yaitu Agmented Reality berbasiskan Vuforia dan Unity untuk studi kasus Gedung $M$ di Universitas Semarang [4], Augmented reality untuk memvisualisasikan objek 2D menjadi 3D[5], Augmented Reality untuk Salesman Canvasing [6], Augmented Reality Objek 3D [7], dan Pengenalan Jenis Laptop menggunakan Metode Makerless [8].

Sedangkan penelitian terkait virtual pet sendiri juga sama pentingnya untuk dipelajari sehingga penelitian di bidang ini terus berkembang dan tidak stagnan atau diulang terus menerus. Berikut beberapa penelitian terdahulu yang kami pelajari:

1. Virtual Pet Simulator Game using Augmented Reality on Android Plaform [9]

Penelitian ini berfokus pada pengembangan virtual pet menggunakan augmented reality vuforia dimana virtual pet bertingkah laku seperti layaknya binatang peliharaan pada umumnya akan tetapi penelitian ini menyimpulkan bahwa tidak mungkin virtual pet menggantikan binatang peliharaan asli.

2. Eva: A Virtual Pet in Augmented Reality [10]

Sama hal nya dengan penelitian sebelumnya. Penelitian ini juga berfokus pada pengembangan virtual pet dengan vuforia akan tetapi tujuan penelitian ini adalah sebuah aplikasi virtual pet yang open source.

3. Walking Your Virtual Dog: Analysis of Awareness and Proxemics with Simulated Support Animals in Augmented Reality [11]

Penelitian ini berfokus pada binatang anjing saja dimana tujuan penelitian ini adalah mempelajari tingkah laku pengguna ketika binatang peliharaannya menghargai orang lain atau ketika orang lain menghargai binatang peliharaannya.

4. Using Augmented Realitu to Enhace Aetherpet, a Prototype of a Social Game [12]

Penelitian ini sama dengan penelitian sebelumnya dimana peneliti berusaha mengembangkan virtual pet menggunakan augmented reality vuforia. Dan disimpulkan augmented reality dapat dikembangkan untuk virtual pet.

\section{DESAIN SISTEM GAME}

Pada bagian ini dijelaskan mengenai arsitektur sistem dari game, alur permainan, serta desain interface yang digunakan pada penelitian ini.

\section{A. Desain Arsitektur Game}

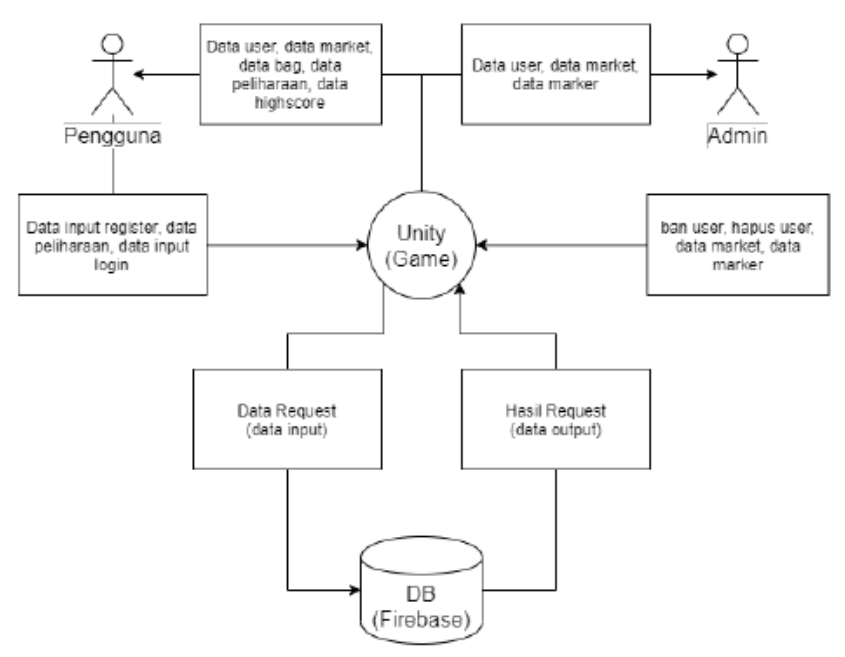

Gambar. 1. Desain Arsitektur Sistem Game

Pada bagian ini dijelaskan mengenai arsitektur sistem (Gambar 1) yang kami gunakan. Desain arsitektur ini menggambarkan gambaran secara sistematis aplikasi pada penelitian ini dimana penggambarannya didasarkan masingmasing role user yang terkait. Terdapat 2 role dalam game ini, yaitu pengguna (user) dan admin. Pengguna dapat membuat akun dengan register, login dan mendapat datadata pengguna seperti username pengguna, nama peliharaan dan jumlah koin yang dimiliki pengguna tersebut. Pengguna juga dapat meletakkan peliharaan dengan melakukan scan pada bidang datar kemudian peliharaan dan objek 3D mini gamenya akan diletakkan (Fitur ini dibuat menggunakan teknologi yang dimiliki oleh AR Foundation yaitu Plane Detection). Pengguna juga dapat bermain mini game dengan menekan objek 3D yang berada di samping peliharaan, di setiap mini game nya juga terdapat menu highscore yang digunakan untuk melihat 10 score tertinggi dan score 
pengguna, setelah pengguna selesai bermain mini game maka pengguna akan diberi koin dan peliharaannya akan diberi experience. Pengguna juga dapat membeli item di market dan item yang dibeli dari market tersebut akan masuk ke bag. Sedangkan role Admin dapat melihat, menghapus dan melakukan ban pada pengguna yang melakukan kecurangan. Admin dapat melihat, menambahkan, mengubah dan menghapus data item makanan yang ada pada market. Dan terakhir, Admin juga dapat melihat, menambahkan, mengubah, menghapus dan memilih marker yang dipakai.

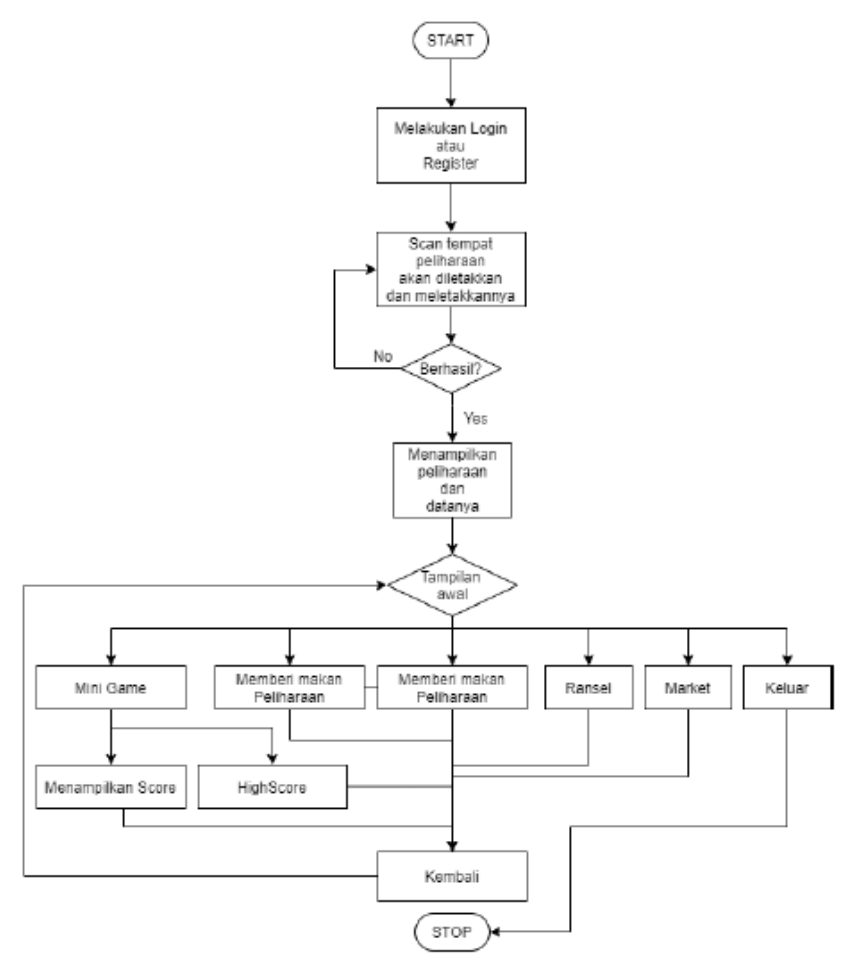

Gambar. 2. Alur Game

Gambar 2 adalah sebuah gambar alur game yang dikembangkan. Pengguna pada awalnya akan diminta untuk melakukan login atau register, setelah itu pengguna diminta untuk melakukan scan ke tempat peliharaan akan diletakkan, jika scan pada tempat yang diinginkan berhasil maka peliharaan akan diletakkan ditempat tersebut. Selanjutnya pengguna akan diberikan tampilan awal yang berupa menu dalam menu tersebut pengguna dapat memilih ransel, market ataupun keluar dari game. Jika pengguna memilih ransel maka pengguna akan diberi tampilan ransel, disana pengguna dapat melihat barang-barang yang dimiliki oleh pengguna tersebut. Jika pengguna memilih market maka pengguna akan diberi tampilan market, disana pengguna dapat membeli barang-barang seperti makanan dan telur. Jika pengguna memilih keluar, maka pengguna akan diarahkan untuk keluar dari game tersebut. Jika pengguna menekan objek 3D yang ada di samping peliharaan yang berhasil diletakkan, maka pengguna akan diarahkan ke mini game sesuai dengan mini game yang pengguna pilih, dalam mini game tersebut pengguna dapat memilih untuk bermain atau melihat HighScore, ketika mini game berakhir pengguna akan diberi tampilan score yang didapatkan. Jika pengguna menekan tombol makan dan melakukan scan pada gambar yang berisi marker, maka pada bagian atas marker tersebut akan muncul objek 3D makanan secara random yang dapat di berikan pada peliharaan, untuk mengganti makanannya pengguna harus mengarahkan kameranya sampai objek 3D makanannya tidak terlihat, maka akan dilakukan random lagi pada makanan yang keluar tersebut. Jika pengguna menekan tombol mandi dan melakukan scan pada gambar yang berisi marker, maka pada bagian atas marker tersebut akan muncul objek 3D tempat mandi yang dapat diberikan pada peliharaan.

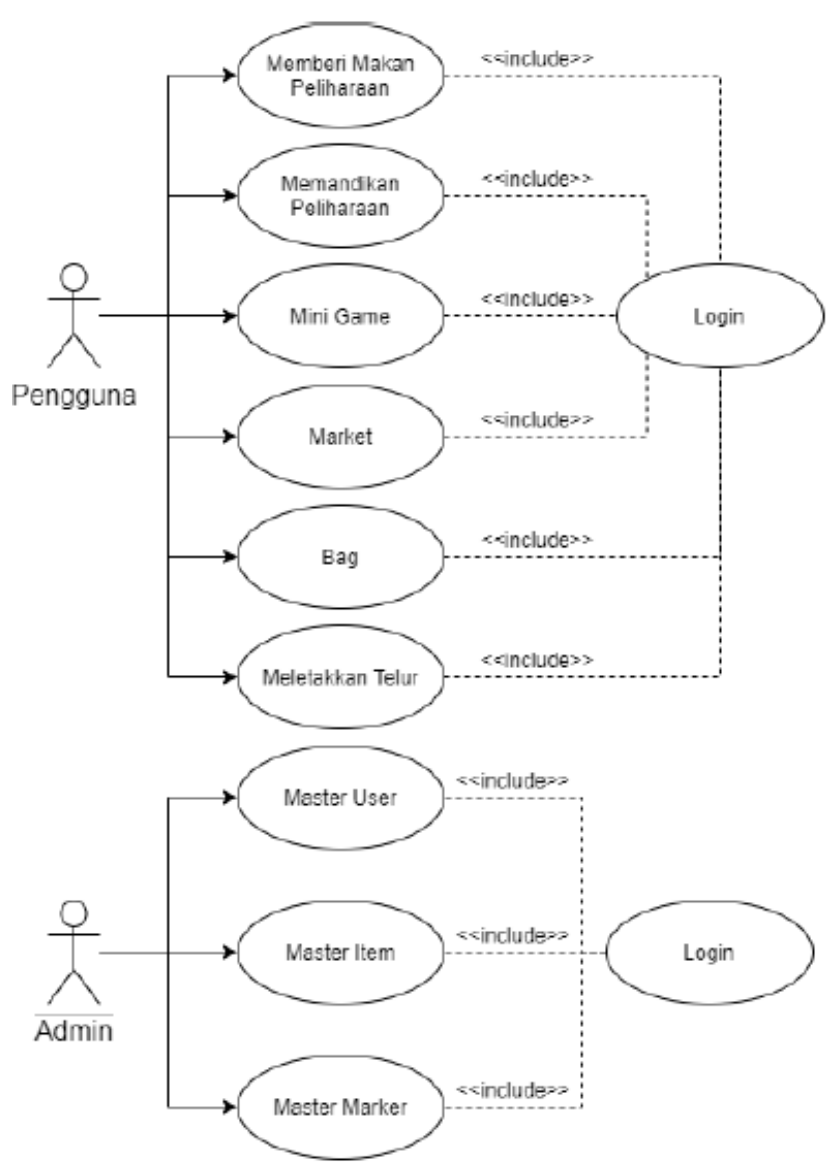

Gambar. 3. Use Case Diagram Sistem Game

Gambar 3 merupakan gambar use case diagram sistem game ini. Terdapat 2 aktor, yaitu pengguna dan admin. Setiap aktor yang melakukan interaksi dengan sistem seperti menggunakan fiturnya harus login ke akun yang telah teregister sebelumnya, setelah itu pengguna dapat memberi makan peliharaan, memandikan peliharaan, memainkan mini game, membeli di market dan melihat bag yang berisi barang atau item yang sudah didapatkan atau dibeli di market. Sedangkan admin dapat melihat data user, melakukan ban pada user yang melakukan kecurangan dan menghapus user pada halaman master user. Admin juga dapat melihat, menambah, mengubah dan menghapus data item yang ada di database pada halaman master item. Selain itu Admin juga dapat melihat, menambah, mengubah, menghapus dan memilih marker yang akan digunakan pada halaman master marker. 


\section{B. Desain Interface Game}

Pada bagian ini akan dijelaskan mengenai tampilan dari game yang dibuat. Bagian ini akan menunjukkan tampilan menurut sudut pandang user, tampilan ini akan terbagi menjadi dua, yaitu tampilan yang dimiliki user dan tampilan yang dimiliki oleh admin. Tampilan yang digunakan oleh user dan admin yang ditampilkan melalui mobile.

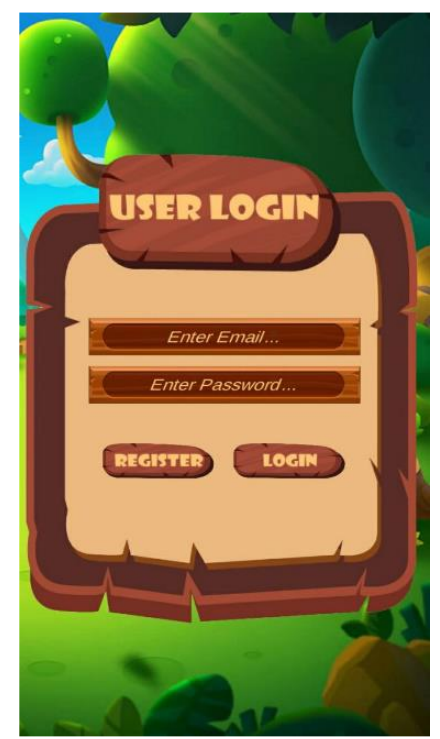

Gambar. 4. Desain User Login

Gambar 4 merupakan tampilan login. Pengguna dapat login apabila pengguna telah membuat akun dibagian registrasi. Jika pengguna belum memiliki akun, pengguna dapat menekan tombol register di kiri bawah untuk langsung diarahkan ke halaman register.

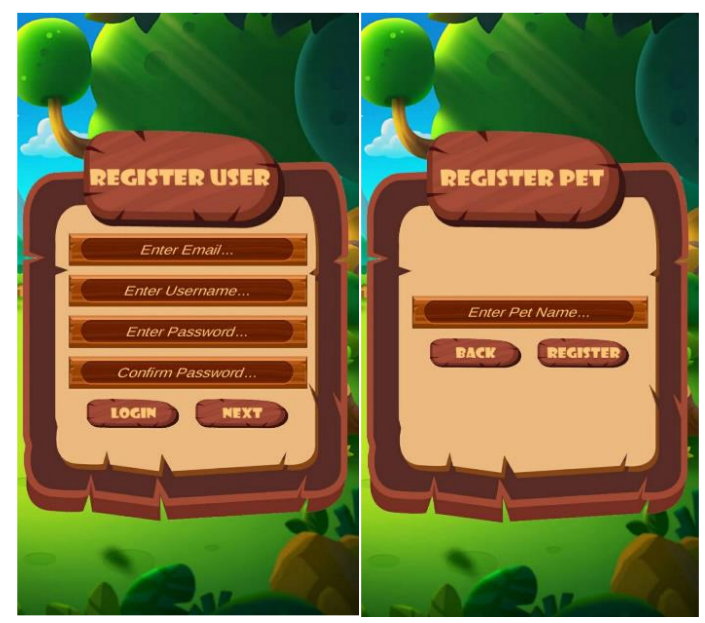

Gambar. 5. Desain User Register

Gambar 5 merupakan tampilan register pengguna. Pengguna dapat membuat akun pada halaman register ini dengan dengan mengisi 5 input yang tersedia pada halaman register pengguna dan halaman register peliharaan dan melewati pengecekan email dan password yang sesuai dengan confirm password, maka akun pengguna akan dibuat.

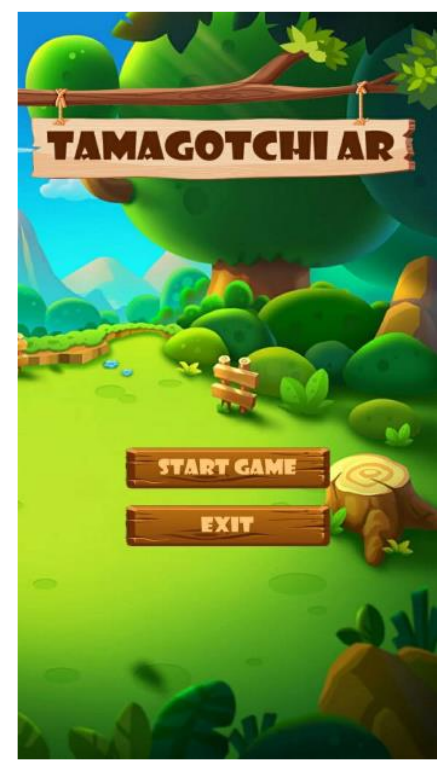

Gambar. 6. Desain Menu Utama

Gambar 6 merupakan tampilan menu awal game. Terdapat 2 tombol yang ada di halaman ini, yaitu tombol start game dan tombol exit. Jika pengguna menekan tombol exit maka pengguna akan diarahkan keluar dari game. Jika pengguna menekan tombol start game maka game akan dimulai dan pengguna akan diminta untuk meletakkan peliharaaannya.

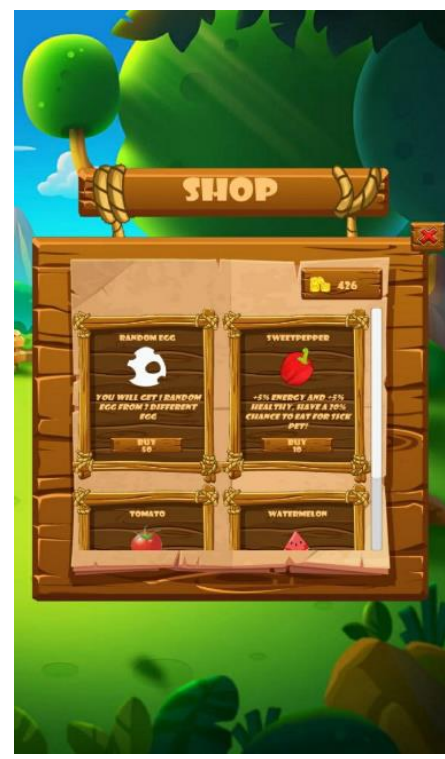

Gambar. 7. Desain Market

Gambar 7 merupakan tampilan market. disini pengguna dapat melihat jumlah koinnya dan dapat membeli item yang diinginkan dengan menekan tombol buy yang ada pada item tersebut. 


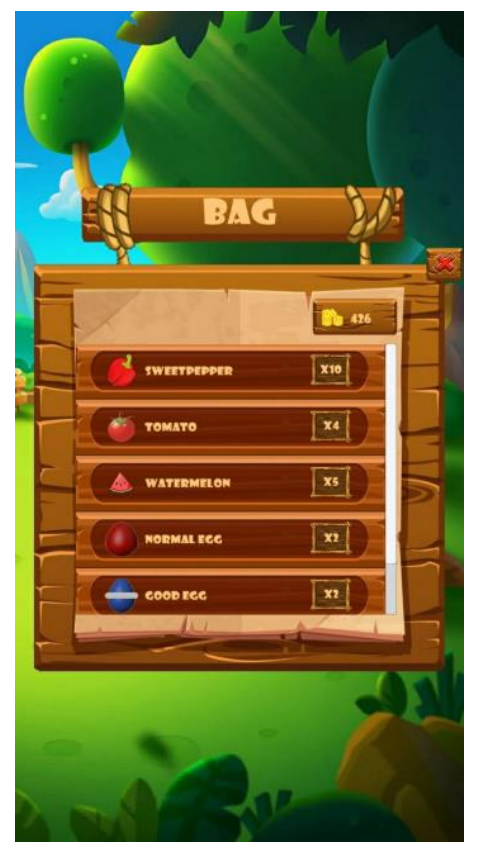

Gambar. 8. Desain Bag Pengguna

Gambar 8 merupakan tampilan bag pengguna. Semua item yang pernah didapat atau dibeli oleh pengguna akan disimpan pada halaman ini, disini juga pengguna dapat melihat jumlah koin yang dimilikinya dan jumlah item yang dimilikinya. Pengguna juga dapat kembali ke halaman sebelumnya dengan menekan tombol silang.

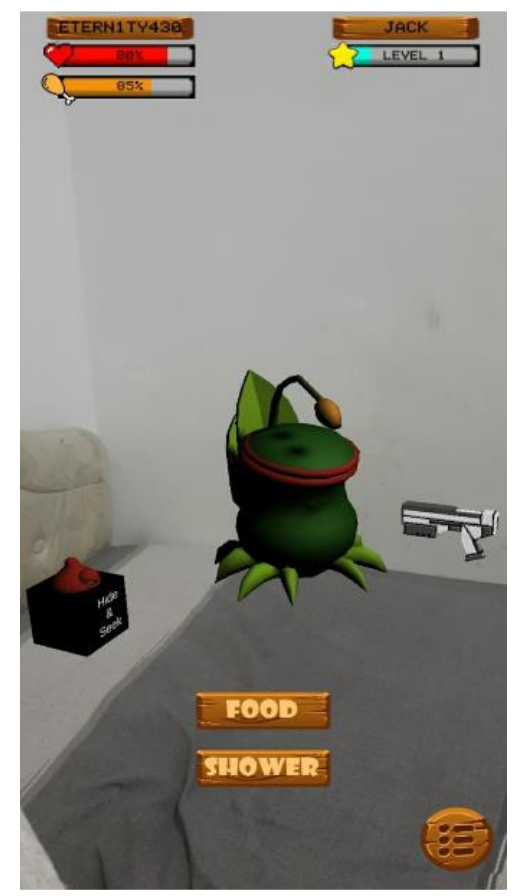

Gambar. 9. Desain Kondisi Virtual Pet

Gambar 9 merupakan tampilan dari permainan virtual pet. Pet akan otomatis muncul saat game medeteksi bidang datar. Disebelah kanan dan kiri pet adalah object 3D yang apabila ditekan akan masuk ke mini games. Terdapat 2 jenis mini games pada permainan ini. Selain mini games, pet juga memiliki status dimana apabila status berkurang harus diberi makan atau dimaindikan.

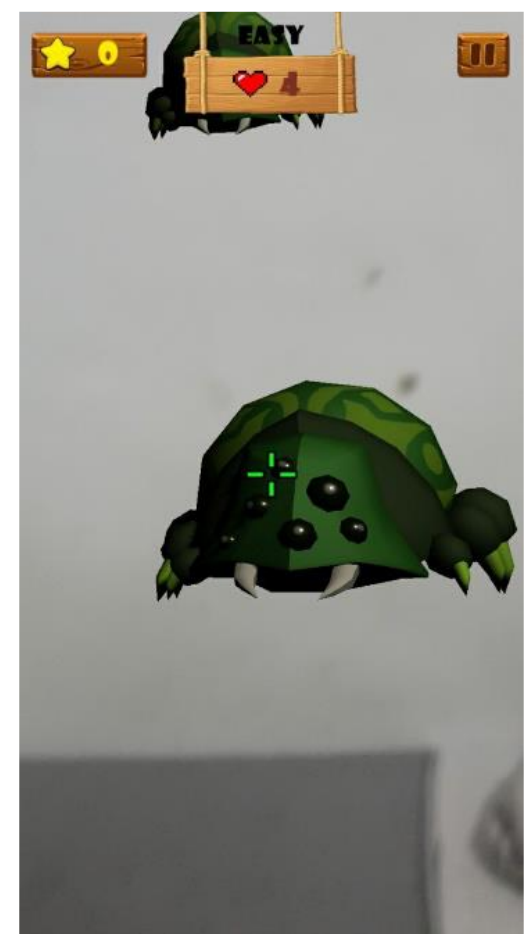

Gambar. 10. Desain Mini Game Pet Shooter

Gambar 10 merupakan tampilan dari mini game Pet Shooter. Pada mini game ini pengguna diminta untuk mencari di dunia nyata dan menembak musuh yang akan spawn terus menerus, score akan bertambah ketika musuh tersebut mati dan game ini akan berakhir ketika nyawa pengguna habis, terdapat juga tombol pause yang berada di kanan atas yang digunakan untuk melakukan pause mini game.

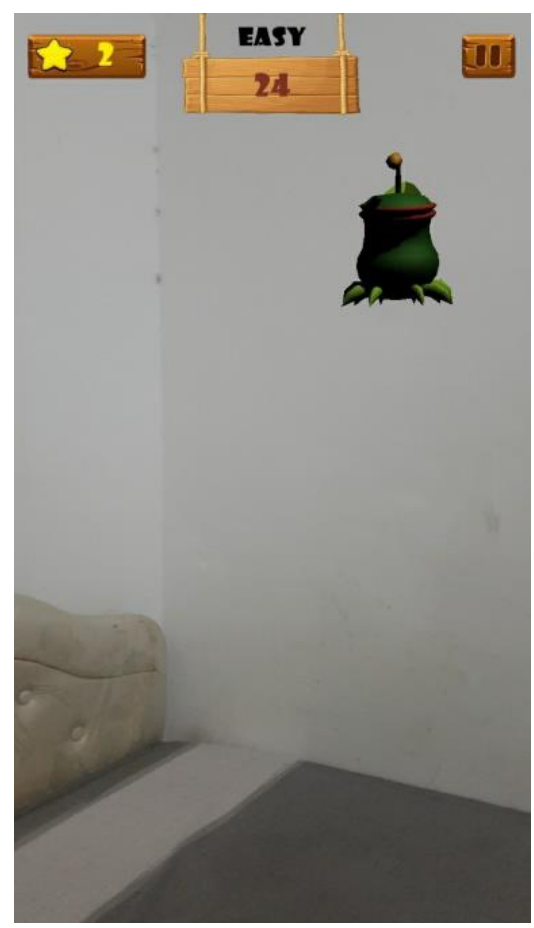

Gambar. 11. Desain Mini Game Hide and Seek

Gambar 11 merupakan tampilan dari minigame Hide And Seek. Pada mini game ini pengguna diminta untuk mencari peliharaannya di dunia nyata, score akan bertambah ketika 
pengguna berhasil menemukan dan menekan peliharaannya, mini game ini akan berakhir ketika waktu yang ditentukan telah habis.

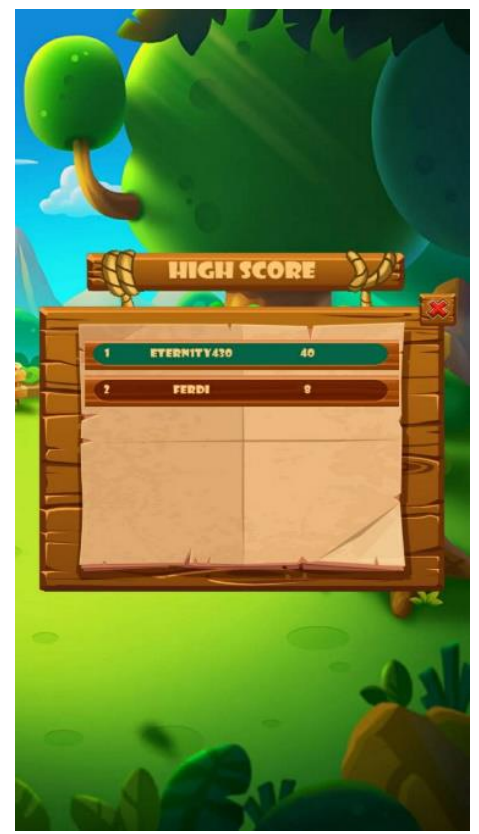

Gambar. 12. Desain High Score pada Mini Games

Gambar 12 merupakan tampilan dari highscore pada mini game. Pada halaman ini pengguna dapat melihat sepuluh score tertinggi dan score tertingginya. Score milik pengguna tersebut akan berwarna hijau dan sisanya akan berwarna cokelat. Jika pengguna menekan tombol silang maka pengguna akan diarahkan kembali ke halaman sebelumnya.

\section{UJI COBA}

Pada tahap ini, akan dijelaskan mengenai hasil uji coba yang telah dilakukan oleh penulis. Diharapkan dengan adanya uji coba ini, penulis dapat mengetahui pendapat orang-orang terhadap game ini.

TABEL I

DAFTAR PERTANYAAN KUISIONER

\begin{tabular}{ll}
\hline \hline No & Pertanyaan \\
\hline 1 & Jenis Kelamin \\
2 & Usia \\
3 & Seberapa Sering Anda Bermain Game \\
4 & Seberapa Sering Anda Bermain Virtual Pet \\
5 & Aapakah Game Berjalan Lancar di Android Anda \\
6 & Apakah AR Berjalan Lancar di Android Anda \\
7 & Berapa Lama Anda Memainkan Game ini \\
8 & Apakah Anda Menikmati Permainan ini \\
9 & Apakah Anda akan Memainkan Game ini lagi jika \\
\hline \hline
\end{tabular}

Metode uji coba pada penelitian ini menggunakan metode kuesioner, namun sebelum mengisi kuesioner 40 responden diminta untuk melakukan uji coba pada game yang dikembangkan selama 3 bulan. Data ini dikumpulkan melalui beberapa pertanyaan yang disusun dalam bentuk kuesioner seperti disajikan pada Tabel I.
TABEL II

HASIL KUISIONER

\begin{tabular}{|c|c|c|c|c|}
\hline $\begin{array}{l}\text { Pertanyaan } \\
\text { Nomor }\end{array}$ & Pilihan I & Pilihan II & Pilihan III & Pilihan IV \\
\hline 3 & $\begin{array}{c}\text { Sangat } \\
\text { Sering } \\
(\mathbf{8 7 . 5 \% )}\end{array}$ & $\begin{array}{l}\text { Sering } \\
(\mathbf{1 2 . 5 \%})\end{array}$ & $\begin{array}{c}\text { Jarang } \\
(\mathbf{0 \%})\end{array}$ & $\begin{array}{c}\text { Tidak } \\
\text { Pernah } \\
(\mathbf{0 \%})\end{array}$ \\
\hline 4 & $\begin{array}{l}\text { Sangat } \\
\text { Sering } \\
(\mathbf{5 0 \%})\end{array}$ & $\begin{array}{l}\text { Sering } \\
(\mathbf{2 0 \%})\end{array}$ & $\begin{array}{l}\text { Jarang } \\
(\mathbf{2 5 \%})\end{array}$ & $\begin{array}{c}\text { Tidak } \\
\text { Pernah } \\
(\mathbf{5 \%})\end{array}$ \\
\hline 5 & $\begin{array}{l}\text { Sangat } \\
\text { Lancar } \\
(\mathbf{8 0 \%})\end{array}$ & $\begin{array}{l}\text { Lancar } \\
(\mathbf{2 0 \%})\end{array}$ & $\begin{array}{c}\text { Kurang } \\
\text { Lancar } \\
(\mathbf{0 \%})\end{array}$ & $\begin{array}{c}\text { Tidak } \\
\text { Berjalan } \\
(\mathbf{0 \%})\end{array}$ \\
\hline 6 & $\begin{array}{l}\text { Sangat } \\
\text { Lancar } \\
(\mathbf{8 2 . 5 \%})\end{array}$ & $\begin{array}{l}\text { Lancar } \\
\mathbf{( 7 . 5 \% )}\end{array}$ & $\begin{array}{l}\text { Kurang } \\
\text { Lancar } \\
\mathbf{( 7 . 5 \% )}\end{array}$ & $\begin{array}{c}\text { Tidak } \\
\text { Berjalan } \\
(\mathbf{2 . 5 \% )}\end{array}$ \\
\hline 7 & $\begin{array}{c}3 \text { bulan } \\
(\mathbf{1 5 \%})\end{array}$ & $\begin{array}{c}>1 \text { bulan } \\
(\mathbf{5 2 . 5 \% )}\end{array}$ & $>\underset{(25 \%)}{1 \text { minggu }}$ & $\begin{array}{l}<1 \text { hari } \\
(\mathbf{7 . 5 \% )}\end{array}$ \\
\hline 8 & $\begin{array}{c}\text { Sangat } \\
\text { Menikmati } \\
(\mathbf{2 2 . 5 \% )}\end{array}$ & $\begin{array}{c}\text { Menikmati } \\
(\mathbf{6 7 . 5 \% )}\end{array}$ & $\begin{array}{c}\text { Kurang } \\
\text { Menikmati } \\
(\mathbf{7 . 5 \% )}\end{array}$ & $\begin{array}{c}\text { Tidak } \\
\text { Menikmati } \\
(\mathbf{2 . 5 \% )}\end{array}$ \\
\hline 9 & Pasti $(\mathbf{2 0 \%})$ & $\begin{array}{c}\text { Sekali- } \\
\text { sekali } \\
(\mathbf{1 7 . 5 \% )}\end{array}$ & $\begin{array}{l}\text { Dipikir } \\
\text { Dahulu } \\
(\mathbf{6 2 . 5 \% )} \\
\end{array}$ & Tidak (0\%) \\
\hline
\end{tabular}

Tabel II merupakan tabel hasil kuisioner yang telah dilakukan pada penelitian ini. Dari sini tampak bahwa responden mayoritas adalah pemain game dan tidak sedikit yang juga merupakan pemain virtual pet. Berdasarkan kuisioner tersebut secara teknis game tidak ada masalah untuk seluruh pengguna tetapi dalam upaya meningkatkan kesenangan dari seorang pemain, game ini dirasa belum cukup. Hal tersebut dapat dilihat dari pertanyaan nomor 7 , dimana hanya $15 \%$ responden yang bermain penuh 3 bulan sedangkan ada $7.5 \%$ responden yang hanya bermain 1 hari saja. Berdasarkan pertanyaan nomor 8 dapat kita lihat juga bahwa terdapat $90 \%$ user yang menikmati permainan ini akan tetapi masih ada $10 \%$ user yang tidak menikmatinya. Sedangkan berdasarkan pertanyaan nomor 9 mayoritas user berpikir dahulu untuk lanjut bermain apabila terdapat update pada permainan. Melihat hal ini, penulis melakukan wawancara singkat kapada beberapa responden yang tidak menikmati game ini dan ditemukan bahwa responden tersebut merasa bosan karena diulang terus, jumlah monster yang diternakan kurang banyak, dan kurangnya fitur terkait monster itu sendiri misalnya seperti alur evolusi dan battle antar monster.

\section{KESIMPULAN}

Pada bagian ini dijelaskan kesimpulan yang didapat selama pembuatan penelitian dimana kesimpulan ini diperoleh dari hasil uji coba yang telah dilakukan. Kesimpulan tersebut adalah sebagai berikut:

1) Game Virtual Pet secara teknis tidak mengalami kendala bahkan dapat berjalan lancar pada berbagai mobile device yang dibuktikan pada kuisioner nomor 5 dan 6 yang menyatakan bahwa $90 \%$ lebih permainan dan AR berjalan lancar.

2) Game Virtual Pet mudah ditinggalkan oleh pemain dikarenakan sifat permainan yang berulang-ulang, hal ini dibuktikan melalui kuisioner nomor 7 dimana terdapat $32.5 \%$ pemain yang berhenti sebelum 1 bulan.

3) Game Virtual Pet kurang meningkatkan kesenangan pemain dalam jangka waktu lama hal ini dapat 
dibuktikan pada pertanyaan nomor 8 yang mayoritas menikmati akan tetapi pada pertanyaan nomor 7 terdapat $35 \%$ pemain yang berhenti bermain sebelum 1 bulan.

\section{DAFTAR PUSTAKA}

[1] J. K. Haas, "A history of the unity game engine," Diss. WORCESTER Polytech. Inst., p. 32, 2014.

[2] Anonymous, "Firebase," 2016. https://firebase.google.com/

[3] C. Wicaksana, "Studi Pengkajian ARCore untuk Pengembangan Aplikasi Augmented Reality pada Android.," 2020.

[4] A. Nugroho and B. A. Pramono, "Aplikasi Mobile Augmented Reality Berbasis Vuforia Dan Unity Pada Pengenalan Objek 3D Dengan Studi Kasus Gedung M Universitas Semarang," J. Transform., vol. 14, no. 2, pp. 86-91, 2017.

[5] Sinarta, "Aplikasi Augmented Reality Berbasis Android untuk Salesman Canvasing," 2017.

[6] N. Wahyudi, R. A. Harianto, and E. Setyati, "Augmented Reality Marker Based Tracking Visualisasi Drawing 2D ke dalam Bentuk 3D dengan Metode FAST Corner Detection," J. Intell. Syst. Comput., vol. 1, no. 1, pp. 9-18, 2019.

[7] E. Ardhianto, W. Hadikurniawati, and E. Winarno, "Augmented Reality Objek 3 Dimensi dengan Perangkat Artoolkit dan Blender," J. Teknol. Inf. Din. Vol., vol. 17, no. 2, pp. 107-117, 2012.

[8] N. Nasruddin, H. Azis, and D. Lantara, "Pengenalan Jenis Laptop menggunakan Metode Markerless," in Prosiding SAKTI (Seminar Ilmu Komputer dan Teknologi Informasi), 2018, vol. 3, no. 2, pp. $148-151$.

[9] J. Chahyana and V. Yesmaya, "Virtual Pet Simulator Game Using Augmented Reality on Android Platform," in Journal of Physics: Conference Series, 2020, vol. 1566, no. 1, p. 12088.

[10] A. Costa, R. Lima, and S. Tamayo, "Eva: a virtual pet in augmented reality," in 201921 st Symposium on Virtual and Augmented Reality (SVR), 2019, pp. 47-51.

[11] N. Norouzi et al., "Walking your virtual dog: Analysis of awareness and proxemics with simulated support animals in augmented reality," in 2019 IEEE International Symposium on Mixed and Augmented Reality (ISMAR), 2019, pp. 157-168.

[12] F. Kwik and R. Bahana, "Using augmented reality to enhance aetherpet, a prototype of a social game," Procedia Comput. Sci., vol. 59, pp. 282-290, 2015. 